\title{
ディスポーザ対応浄化槽の $\mathrm{LCCO}_{2}$ 評価
}

\author{
Life Cycle $\mathrm{CO}_{2}$ Evaluation for Household Johkasou System with Garbage Disposer
}

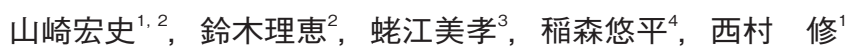

${ }^{1}$ 東北大学大学院工学研究科 $/$ T 980-8579 仙台市青葉区荒巻字青葉6-6-06

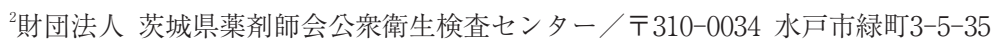

3独立行政法人 国立環境研究所 $/$ ○ 305-8506 つくば市小野川16-2

4福島大学共生システム理工学類 $/$ † 960-1296 福島市金谷川1

HIROSHI YAMAZAKI I, ${ }^{1,}$ RIE SUZUKI ${ }^{2}$, YOSHITAKA EBIE ${ }^{3}$, YUHEI INAMORI ${ }^{4}$, and OSAMU NISHIMURA ${ }^{1}$

${ }^{1}$ Faculty of Engineering, Tohoku University

/ 6-6-06, Aoba, Aramaki, Aoba, Sendai, Miyagi, 980-8579, Japan

${ }^{2}$ Ibaraki Pharmaceutical Association / 3-5-35 Midori, Mito, Ibaraki, 310-0034, Japan

${ }^{3}$ National Institute for Environmental Studies / 16-2 Onogawa, Tsukuba, Ibaraki, 305-8506, Japan

${ }^{4}$ Faculty of Symbiotic Systems Science, Fukushima University

/ 1 Kanayagawa, Fukushima, Fukushima, 960-1296, Japan

\begin{abstract}
Life cycle $\mathrm{CO}_{2}$ evaluation of kitchen garbage treatment in a house using Johkasou was conducted to compare the impacts of two scenarios. First one is a present case in which kitchen garbage is incinerated with other domestic waste and treats domestic wastewater in Johkasou, and second case is a simultaneous treatment of domestic wastewater and kitchen garbage in household Johkasou. In the second case, disposer was used for kitchen garbage and newly developed Johkasou for this case was used. Potential contributions of these two cases to $\mathrm{CO}_{2}$ emission in the processes of waste treatment and domestic wastewater treatment were assessed by LCA. A case of a simultaneous treatment of kitchen garbage and domestic wastewater decreased in transportation amount of domestic waste and net $\mathrm{CO}_{2}$ emission was reduced by $7.8 \%$ (39.9 $\mathrm{kg}^{-} \mathrm{CO}_{2}$ house $^{-1}$ year $\left.{ }^{-1}\right)$. Because transportation of domestic waste influences $\mathrm{CO}_{2}$ emission to a greater degree than in Johkasou sludge transportation, a simultaneous treatment process of kitchen garbage and domestic wastewater can reduce more $\mathrm{LCCO}_{2}$ when the transportation distance of domestic waste is long.
\end{abstract}

Keywords: Disposer, Johkasou, Life Cycle Assessment, Environmental Impact

\section{1.はじめに}

1997年、京都において開催された地球温暖化防止京都 会議の成果をもとに京都議定書が作成され、その中で日 本は、2010年までに1990年比で 6 \%の温室効果ガス排出 量を削減すると目標を定め、以後、様々な分野で温室効
果ガス排出削減の取り組みがなされてきており、下水道 や浄化槽といった排水処理システムにおいても温室効果 ガスの排出を削減する必要がある。また、日本における 生活排水処理システムの整備が、大都市地域から中山間 地域に移行してきている現状を踏まえると、今後は個別 分散型の排水処理システムを中心とした温室効果ガス削 
減技術の開発が重要である。

ディスポーザは、台所の排水口に設置され、生ごみを 破砕し排水とともに流し、生ごみを排水処理に供するこ とを可能とする設備で、米国では一般的に広く普及して いる1 。一方、日本では、旧建設省における総合技術開 発プロジェクト「ディスポーザーによる「生ごみリサイ クルシステムの開発」」2)により、ディスポーザ排水と台 所排水を併せて排水処理槽で処理した後、下水道等に放 流する「ディスポーザ排水処理システム」とディスポー ザ排水と生活排水を併せて合併処理浄化槽で処理し、公 共用水域へ放流する「ディスポーザ対応浄化槽」が提案 され、以降、建設大臣による認定が開始されている。特 に「ディスポーザ排水処理システム」は、認定開始以降、 生ごみを衛生処理できる利便性が評価され、大都市圈を 中心に急速に普及が進んでいる3”。また、近年では、下 水道地域においてディスポーザ排水を直接下水道へ導入 する場合の考え方を示した「ディスポーザー導入時にお ける影響判定の考え方」 ${ }^{11}$ が公開されるとともに、浄化 槽地域への設置が可能なディスポーザ対応浄化槽の性能 評価 $^{4)}$ も開始されており、日本各地においてディスポー ザを活用した排水処理システムの導入に関する検討がな され始めている状況である。

このような社会背景の中で、ディスポーザを用いた排 水処理システムが、生ごみの衛生処理といった利便性だ けでなく、污水処理設備が本来有している排水の処理性 能を維持し、公共用水域への環境保全に寄与するのみな らず、環境への総合的な影響を明らかにする必要がある。 特にディスポーザを用いた排水処理システムの普及によ り、生ごみが廃棄物処理から排水処理へ移行することに より、従来、別々に考えられてきた廃衰物処理と排水処 理という 2 種のプロセスの地域全体の環境に及ぼす影響 変化が考えられる。豊貞らは既に下水道地域におけるデ イスポーザ導入前後の $\mathrm{CO}_{2}$ 排出量変化を種々の導入形態 で評価しており ${ }^{5-7}$ 、西村らは、生活排水処理計画を立 案する上で、下水道と浄化槽あるいは排水の高度処理化 やその規模に対して、LCA評価を実施する重要性を明ら かとしている ${ }^{8)}$ が、ディスポーザ対応浄化槽の普及により、 地域全体の廃棄物処理と排水処理という 2 種のプロセス の変化に対する環境への影響について検討された事例は ない。

本研究では、上記の点を踏まえ、浄化槽地域の戸建住 宅を対象に、生活排水を構造例示型浄化槽 ${ }^{9)}$ で処理し、 生ごみを含む全ての生活系ごみをごみ焼却場で処理する ケース（以下、「標準処理ケース：Case 1」という。）と
生活排水とともに生ごみをデイスポーザ対応浄化槽で処 理し、生ごみを除く生活系ごみをごみ焼却場で処理する ケース（以下、「ディスポーザ対応浄化槽導入ケース： Case 2」という。）を例に、地域全体における廃棄物処 理と排水処理の変化に対する環境への影響を明らかにす るために、 $\mathrm{CO}_{2}$ 排出量変化に着目し、 $\mathrm{LCCO}_{2}$ を比較定量 評価した。また、これらの評価結果から、ディスポーザ 対応浄化槽の普及による生ごみ処理の廃棄物処理から排 水処理への移行が地域全体から発生する $\mathrm{CO}_{2}$ 排出量に及 ぼす影響を明らかにし、廃棄物処理と排水処理という 2 種のプロセスの環境影響評価の考え方について明らかと することを目的として検討を行った。

\section{2. 試算方法}

\section{1 試算モデルの設定}

本研究では、Case 1（標準処理ケース）と Case 2（デ イスポーザ対応浄化槽導入ケース）におけるLCA試算 モデルをFig. 1のとおり定義し、これらの各工程におけ る $\mathrm{CO}_{2}$ 排出量を明らかにし、比較評価することを目的と した。本研究において試算対象とした排水処理および廃 棄物処理における各工程はTable 1 に示すとおりである。 本研究では、LCA評価に広く用いられている積上げ法と 産業連関法を併用した評価手法により、 $\mathrm{CO}_{2}$ 排出量を指 標としたインベントリー分析 $\left(\mathrm{LCCO}_{2}\right.$ 評価）を行うこ ととした。本評価に用いた排水処理工程における構造例 示型浄化槽は国土交通大臣が定めた構造方法の浄化槽と し、一方、ディスポーザ対応浄化槽は、浄化槽の性能評 価を取得し、国土交通大臣の認定を受けている浄化槽と した。また、本研究では両浄化槽とも浄化槽の最小規模 である 5 人槽を対象とした。本研究で比較対象とした両 浄化槽の仕様はTable 2 に示すとおりである。本評価に 用いた生活系ごみの発生量は、環境省より報告された生 活系ごみの全国発生総量 3,453 万 $\mathrm{t}^{10)}$ を一人たりに換 算した $743 \mathrm{~g} /($ 人・日）とし、浄化槽の人員算定に合わせ、 5 人/戸とした。また、生ごみ発生量に関しては、地域 特性により様々の報告がなされているが7、本研究では、 「浄化槽の性能評価試験方法」) に規定されている250g/ (人・日）とし、生活排水およびディスポーザ排水の排 水量もそれに準拠し、生活排水量は200l/(人・日)、デ イスポーザ排水量は $5 l$ l(人・日）とした。また、生ご みと生ごみを除いた生活系ごみの含水率を Fig.1に合わ せて示した ${ }^{11)}$ 。本研究では廃棄物の含水率は試算の対象 とはしていないが、ディスポーザの導入により、含水率 

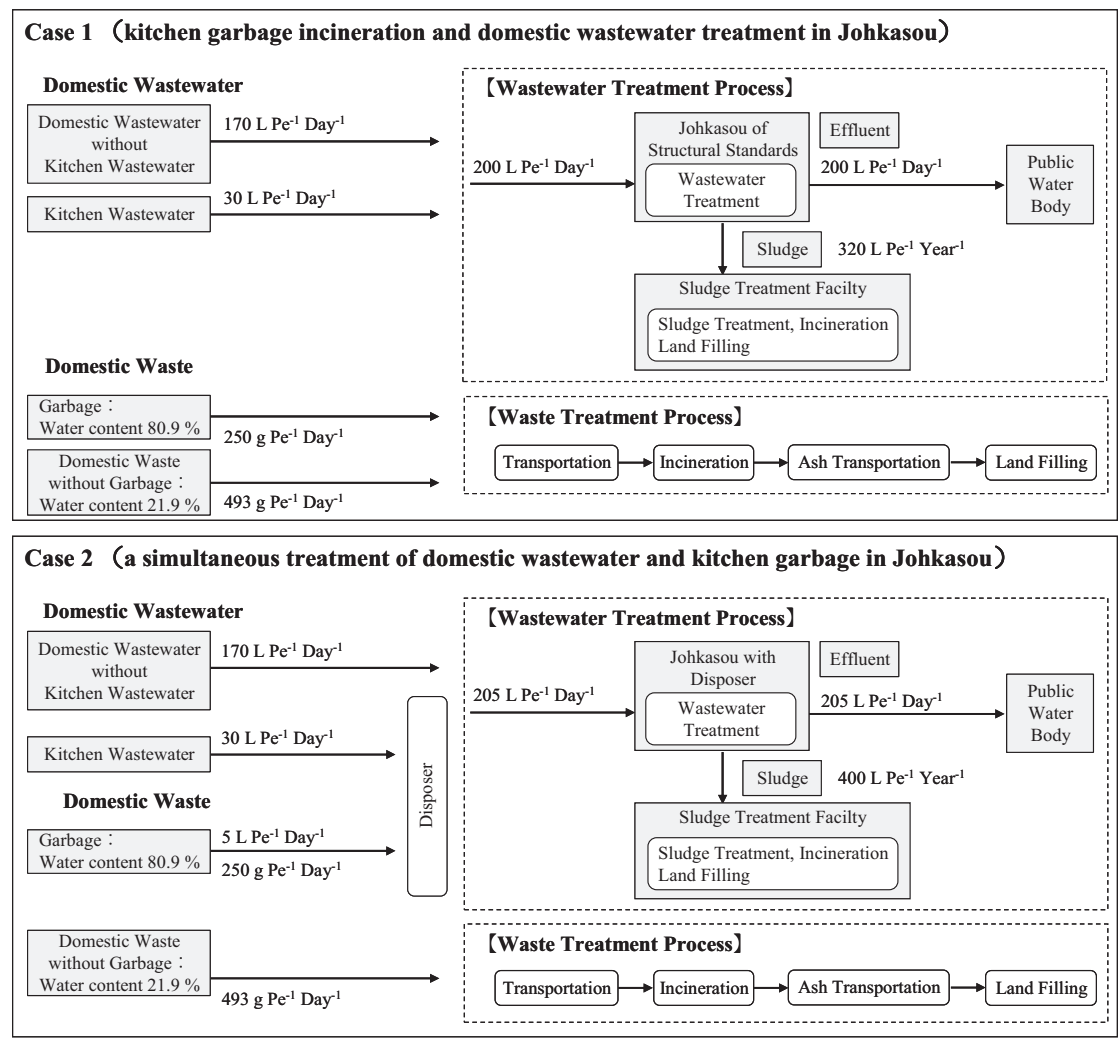

Fig. 1 Scenarios investigated in this study.

Table 1 Simulated Process in this study.

\begin{tabular}{|c|c|c|}
\hline \multirow{2}{*}{$\begin{array}{l}\text { Wastewater } \\
\text { Treatment } \\
\text { Process }\end{array}$} & $\begin{array}{l}\text { Production/ } \\
\text { Installation } \\
\quad \text { Stage }\end{array}$ & $\begin{array}{l}\text { Johkasou Production, Johkasou Transportation, Johkasou Installation, } \\
\text { Disposer Production / Transportation / Installation, } \\
\text { Cesspit Cleaner Truck Production, Sludge Treatment Facility Construction, } \\
\text { Ash Land filling Construction }\end{array}$ \\
\hline & $\begin{array}{l}\text { Operation } \\
\text { Stage }\end{array}$ & $\begin{array}{l}\text { Johkasou Electric Power (Blower), } \mathrm{N}_{2} \mathrm{O} \text { Output for Wastewater Treatment, } \\
\text { Disposer Electric Power, Sludge Transportation Fuel, Sludge Incineration Fuel, } \\
\text { Sludge Intermediate Disposal, } \mathrm{N}_{2} \mathrm{O} \text { Output for Sludge Incineration, } \\
\text { Sludge Ash Transportation Fuel, Sludge Ash Land Filling }\end{array}$ \\
\hline \multirow{2}{*}{$\begin{array}{l}\text { Waste } \\
\text { Treatment } \\
\text { Process }\end{array}$} & $\begin{array}{l}\text { Production/ } \\
\text { Installation } \\
\quad \text { Stage }\end{array}$ & $\begin{array}{l}\text { Waste Truck Production, Waste Incineration Facility Construction, } \\
\text { Waste Ash Transportation Car Production, } \\
\text { Waste Ash Land Filling Facility Construction }\end{array}$ \\
\hline & $\begin{array}{l}\text { Operation } \\
\text { Stage }\end{array}$ & $\begin{array}{l}\text { Waste Transportation Fuel, Waste Incineration Fuel, } \\
\mathrm{N}_{2} \mathrm{O} \text { Output for Waste Incineration, Waste Ash Transportation Fuel, } \\
\text { Waste Ash Land Filling }\end{array}$ \\
\hline
\end{tabular}


Table 2 Design Specific data of Johkasou.

\begin{tabular}{|c|c|c|}
\hline & $\begin{array}{c}\text { Johkasou of } \\
\text { Structural Standards }\end{array}$ & Johkasou with Disposer \\
\hline Designed Number of Users & 5 Person & 5 Person \\
\hline Treatment Process & $\begin{array}{l}\text { Anaerobic filter contact } \\
\text { aeration process }\end{array}$ & $\begin{array}{l}\text { Flow equalization type solid-liquid } \\
\text { separation anaerobic filter fluidized } \\
\text { bed with circulation process }\end{array}$ \\
\hline Effective Volume & $3.014 \mathrm{~m}^{3}$ & $3.067 \mathrm{~m}^{3}$ \\
\hline Designed Influent Water Volume & $200 l \mathrm{Pe}^{-1} \mathrm{Day}^{-1}$ & $\begin{array}{l}205 l \mathrm{Pe}^{-1} \text { Day }^{-1} \\
(\text { Disposer Wastewater : } \\
\left.5 l \mathrm{Pe}^{-1} \text { Day }^{-1}\right)\end{array}$ \\
\hline Designed Influent BOD Concentration & $200 \mathrm{mg} l^{-1}$ & $330 \mathrm{mg} l^{-1}$ \\
\hline Designed Effluent BOD Concentration & $20 \mathrm{mg} l^{-1}$ & $15 \mathrm{mg} l^{-1}$ \\
\hline Amount of Designed Garbage & - & $250 \mathrm{~g} \mathrm{Pe}^{-1}$ Day $^{-1}$ \\
\hline Designed Amount of Sludge Discharged & $1.6 \mathrm{~m}^{3} \mathrm{Year}^{-1}$ & $2.0 \mathrm{~m}^{3} \mathrm{Year}^{-1}$ \\
\hline $\begin{array}{l}\text { Amount of Electricity Used } \\
\text { (Blower) }\end{array}$ & $\begin{array}{l}420.48 \mathrm{kWh} \text { Year }^{-1} \\
\text { (Electric Volume } 60 \mathrm{~W} \text {, } \\
\text { Power Factor } 0.8 \text { ) }\end{array}$ & $\begin{array}{l}420.48 \mathrm{kWh} \mathrm{Year}^{-1} \\
\text { (Electric Volume } 60 \mathrm{~W} \text {, } \\
\text { Power Factor 0.8) }\end{array}$ \\
\hline Amount of Disinfectant & $2030 \mathrm{~g} \mathrm{Year}^{-1}$ & 2030 g Year $^{-1}$ \\
\hline Operation Process for Disposer & - & Manually Water Fed \\
\hline $\begin{array}{l}\text { Amount of Electricity Used } \\
\text { (Disposer) }\end{array}$ & - & $300 \mathrm{~W}$ \\
\hline Weight of Disposer Body & - & $8.8 \mathrm{~kg}$ \\
\hline
\end{tabular}

の高い生ごみが廃棄物処理から排水処理に移動すること により、生活系ごみの焼却に伴う助燃料の削減効果も期 待できると考えられる。

\section{2. $2 \mathrm{LCCO}_{2}$ 評価方法}

Fig. 1で定義したCase 1（標準処理ケース）と Case 2 （ディスポーザ対応浄化槽導入ケース）の各モデルにお いて、排水処理と廃妄物処理における製造・施工段階と 運用段階の各工程における $\mathrm{CO}_{2}$ 排出量を試算し、全体の $\mathrm{LCCO}_{2}$ を算出し比較評価を行った。なお、各工程からの 製品廃棄段階については、建設物や建築設備の廃棄段階 における環境負荷のライフサイクル全体に占める割合が 非常に小さいとの報告がなされている ${ }^{12)}$ ため、本試算か ら除外した。各工程の試算方法を以下に示す。

\section{1) 廃棄物処理工程}

生活系ごみの輸送は、使用車両 $2 \mathrm{t}$ パッカー車、燃費 $3 \mathrm{~km} / l$ とした。製造・施工段階における車両製造にか かわる $\mathrm{CO}_{2}$ 排出量は走行時に発生する $\mathrm{CO}_{2}$ 排出量の 12.9 \%として求めた ${ }^{5}$ 。また、運用段階は、生活系ごみの輸 送距離を下水道地域における文献值 ${ }^{5)}$ から $30 \mathrm{~km}$ を基準 点とし、車両の軽油消費量から走行時の $\mathrm{CO}_{2}$ 排出量を求
め、これと維持管理にかかる $\mathrm{CO}_{2}$ 発生量（走行時の1.63 \%)の合計を運用段階の $\mathrm{CO}_{2}$ 発生量原単位とした。また、 浄化槽地域では住宅密集度が低く住宅間の距離も長いこ とが考えられたため、本研究では、生活系ごみの輸送距 離を $10 \mathrm{~km}$ から $50 \mathrm{~km}$ まで変化させた場合の $\mathrm{LCCO}_{2}$ につい ても併せて検討した。

生活系ごみの焼却、埋立の製造・施工段階は、環境省 による平成14年度の一般廃棄物処理事業実態調査の建設 改良費報告值 ${ }^{13)}$ を一般廃棄物の総排出量で除して、単位 ごみ量当たりの建設改良費を求め、これに産業連関表基 準の「その他土木建設」の $\mathrm{CO}_{2}$ 排出量原単位を乗じて求 めた ${ }^{7)}$ 。また、運用段階は、ごみ焼却における電力、助 燃料消費にかかる $\mathrm{CO}_{2}$ 排出量を求めた。また、地球温暖 化への影響評価指標として生活系ごみ焼却によるカーボ ン由来ではない $\mathrm{N}_{2} \mathrm{O}$ の影響と最終処分場の延命効果は考

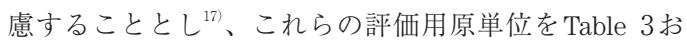
よびTable 4 に示した。また、 $\mathrm{N}_{2} \mathrm{O}$ に関しては、Table 4 に示す地球温暖化係数を基に $\mathrm{CO}_{2}$ ベースの負荷量に換算 した。なお、生活系ごみ焼却による $\mathrm{CH}_{4}$ の影響については、 排出係数、地球温暖化係数ともに $\mathrm{N}_{2} \mathrm{O} 、 \mathrm{CO}_{2}$ と比較して 十分に影響が小さいことから ${ }^{177}$ 、試算対象外とした。そ のため、ごみ焼却時の運用段階は $\mathrm{CO}_{2}$ とごみ焼却時の 
$\mathrm{N}_{2} \mathrm{O}$ 発生量 $\left(\mathrm{CO}_{2}\right.$ 換算值）の合計値とした。

ごみ焼却灰の輸送は、使用車両10tパッカー車、燃費 $3.3 \mathrm{~km} / l$ とした。製造・施工段階における車両製造にか かわる $\mathrm{CO}_{2}$ 排出量は走行時に発生する $\mathrm{CO}_{2}$ 排出量の 12.9 \%として求めた ${ }^{5)}$ 。また、運用段階は、焼却灰の輸送距 離を文献值から $20 \mathrm{~km}$ と設定し、車両の軽油消費量から走 行時の $\mathrm{CO}_{2}$ 排出量を求め、これと維持管理にかかる $\mathrm{CO}_{2}$ 発生量（走行時の $1.63 \%$ ) の合計を運用段階の $\mathrm{CO}_{2}$ 発生量 原単位とした。また、焼却灰輸送距離については $\mathrm{LCCO}_{2}$ 評価結果への影響が微小であるという報告がなされてい るため ${ }^{6)}$ 、設定值による試算のみとした。

最終処分場の延命効果については、デイスポーザによっ て削減されるごみ量から焼却後の埋立量を求め、Table 4 の埋立容積あたりの建設費、 $\mathrm{CO}_{2}$ 発生量原単位から算出

Table 3 Standard Unit for Estimation.

\begin{tabular}{|c|c|}
\hline Item & Standard Unit \\
\hline Others Civil Construction ${ }^{14)}$ & $\begin{array}{c}3818.07 \mathrm{~kg}-\mathrm{CO}_{2} \\
\text { Million yen }\end{array}$ \\
\hline Waste Treatment $(\text { Public })^{14)}$ & $\begin{array}{l}2305.16 \mathrm{~kg}-\mathrm{CO}_{2} \\
\text { Million yen }\end{array}$ \\
\hline Processing (Pump $\cdot$ Blower $)^{15)}$ & $0.4 \mathrm{~kg}-\mathrm{CO}_{2} \mathrm{~kg}^{-1}$ \\
\hline Processing of Injection ${ }^{16)}$ & $0.450 \mathrm{~kg}-\mathrm{CO}_{2} \mathrm{~kg}^{-1}$ \\
\hline Electric Power ${ }^{17)}$ & $0.368 \mathrm{~kg}-\mathrm{CO}_{2} \mathrm{kWh}^{-1}$ \\
\hline Water $^{18)}$ & $0.279 \mathrm{~kg}-\mathrm{CO}_{2} \mathrm{~m}^{-3}$ \\
\hline Soda Industry Product* & $0.824 \mathrm{~kg}-\mathrm{CO}_{2} \mathrm{~g}^{-1}$ \\
\hline Diesel $^{14)}$ & $2.644 \mathrm{~kg}-\mathrm{CO}_{2} l^{-1}$ \\
\hline
\end{tabular}

Table 4 Standard Unit for $\mathrm{N}_{2} \mathrm{O}$ Output/Construction of Final Disposal Site.

\begin{tabular}{|c|c|}
\hline Item & Standard Unit \\
\hline $\mathrm{N}_{2} \mathrm{O}$ Global Warming Potential ${ }^{17)}$ & 310 \\
\hline $\begin{array}{l}\mathrm{N}_{2} \mathrm{O} \text { Output Cofficient for } \\
\text { Incineration of Waste }\end{array}$ & $0.0565 \mathrm{~kg}-\mathrm{N}_{2} \mathrm{O} \mathrm{t}^{-1}$ \\
\hline $\begin{array}{c}\mathrm{N}_{2} \mathrm{O} \text { Output Cofficient for } \\
\text { Wastewater Treatment System }{ }^{17)} \\
\text { (Mainly Johkasou) }\end{array}$ & $0.026 \mathrm{~kg}-\mathrm{N}_{2} \mathrm{O} \mathrm{Pe}$ \\
\hline $\begin{array}{l}\mathrm{N}_{2} \mathrm{O} \text { Output Cofficient for } \\
\text { Incineration of Sludge }\end{array}$ & $0.645 \mathrm{~kg}-\mathrm{N}_{2} \mathrm{O} \mathrm{t}^{-1 \%}$ \\
\hline $\begin{array}{c}\mathrm{CO}_{2} \text { Output for Construction of } \\
\text { Final Disposal Site }\end{array}$ & $\begin{array}{l}4.668 \mathrm{~kg}-\mathrm{CO}_{2} \\
\text { Thousand yen }\end{array}$ \\
\hline $\begin{array}{c}\text { Cost of Construction for Final } \\
\text { Disposal Site / Land Filling } \\
\text { Volume }^{7)}\end{array}$ & 10,000 yen $\mathrm{m}^{-3}$ \\
\hline
\end{tabular}

※ Sludge Cake (ton)
した。ごみ焼却減容率 $\left.{ }^{5}\right)$ は 0.15 、覆土量 ${ }^{1)}$ は $0.17 \mathrm{~m}^{3}$ /埋立 $\mathrm{m}^{3}$ とした。以上より算定した廃棄物処理工程の $\mathrm{CO}_{2}$ 排出 量原単位をTable 5 に示した。

\section{2 ) 排水処理工程}

排水処理工程における製造・施工段階の $\mathrm{CO}_{2}$ 排出量は、 本研究で比較対象とした構造例示型浄化槽とディスポー ザ対応浄化槽における材料調達段階、加工段階、輸送段 階、施工段階の合計とした。材料調達段階は、構造例示 型浄化槽とディスポーザ対応浄化槽に使用されている材 料毎の重量に、産業連関表基準の原単位を乗じ、部位毎 の耐用年数（浄化槽本体：30年、ブロワ：12年）で除し て、 1 年間に排出される材料調達段階の $\mathrm{CO}_{2}$ 排出量を求 めた。各浄化槽の主要材料名、材料別重量と試算に使用 した $\mathrm{CO}_{2}$ 排出量原単位をTable 6 に示した。ディスポー ザ部については既報の数值を採用した ${ }^{6)}$ 。加工段階につ いては、 $\mathrm{CO}_{2}$ 排出量原単位の報告值が非常に少ないため、 ディスポーザおよび浄化槽本体を対象とし、ディスポー ザ本体はポンプ・ブロワの加工原単位報告值を使用し、 浄化槽本体はインジェクション成型法において製作する ための原単位を使用し、材料調達段階と同様、耐用年数 で除して 1 年あたりの $\mathrm{CO}_{2}$ 排出量を求めた。輸送段階は、 使用車両を $10 \mathrm{t}$ 車、車両 1 台あたり浄化槽 6 基積載、輸 送距離を $500 \mathrm{~km}$ として ${ }^{20)}$ 、各浄化槽を製造拠点から倉庫 まで輸送する際に使用する燃料消費量に基づき試算した $\mathrm{CO}_{2}$ 排出量を、各耐用年数で除して求めた。デイスポー ザ部については既報の数值を採用した ${ }^{5)}$ 。施工段階は、 施工機械を使用する土木コンクリート工事のみを算定対 象とし、各浄化槽の土木コンクリート工事費用に、産業 連関表基準 ${ }^{14)}$ の「その他土木建設」の $\mathrm{CO}_{2}$ 発生量原単位 (Table 3) を乗じて求めた。

運用段階の $\mathrm{CO}_{2}$ 排出量は、各浄化槽の電力 · 薬剤 · 水 使用と、污泥輸送・污泥処理の合計とした。各浄化槽に

Table $5 \mathrm{CO}_{2}$ Output Standard Unit for Waste Treatment Process.

\begin{tabular}{ccc}
\hline \multirow{2}{*}{ Item } & $\mathrm{CO}_{2}$ Output Standard Unit $\left(\mathrm{kg}-\mathrm{CO}_{2} \mathrm{t}^{-1}\right)$ \\
\cline { 2 - 3 } $\begin{array}{c}\text { Construction/ } \\
\text { Installation Stage }\end{array}$ & $\begin{array}{c}\text { Operation } \\
\text { Stage }\end{array}$ \\
\hline Transportation & 2.62 & 20.67 \\
Incineration & 52.69 & 97.52 \\
Ash Transportation & 0.03 & 0.24 \\
Land Filling & Including Incineration & 2.45 \\
\hline
\end{tabular}


Table $6 \mathrm{CO}_{2}$ emission rate and Johkasou material weight.

\begin{tabular}{|c|c|c|c|}
\hline \multirow[b]{2}{*}{ Main Material } & \multirow{2}{*}{$\begin{array}{l}\mathrm{CO}_{2} \text { emission } \\
\text { rate on weight } \\
\text { basis } \\
\left(\mathrm{kg}-\mathrm{CO}_{2} \mathrm{~kg}^{-1}\right)\end{array}$} & \multicolumn{2}{|c|}{ Johkasou material weight $\left(\mathrm{kg}\right.$ reactor $\left.{ }^{-1}\right)$} \\
\hline & & $\begin{array}{c}\text { Johkasou of } \\
\text { Structural } \\
\text { Standards }\end{array}$ & $\begin{array}{l}\text { Johkasou with } \\
\text { Disposer }\end{array}$ \\
\hline Unsaturated Polyester & 1.31 & 180 & 240 \\
\hline Resins of Polypropylene & 1.10 & 36 & 51.5 \\
\hline Resins of Polyvinyl Chloride & 0.87 & 10 & 32 \\
\hline Others Steel Products & 1.68 & 11.5 & 13.5 \\
\hline Others Synthetic Resins Plastics & 1.35 & 19.5 & 20 \\
\hline
\end{tabular}

おいて排水処理に伴い発生する $\mathrm{CO}_{2}$ 排出量は、カーボン ニュートラルとして大気中の $\mathrm{CO}_{2}$ を増加させないことか ら試算対象外としたが、排水処理に伴い発生する $\mathrm{N}_{2} \mathrm{O}$ の 影響については考慮することとし、評価用原単位をTable 4に示した。なお、 $\mathrm{CH}_{4}$ の影響については、廃棄物処理 工程と同様に $\mathrm{N}_{2} \mathrm{O} 、 \mathrm{CO}_{2}$ と比較して十分に影響が小さい ことから ${ }^{17)}$ 、試算対象外とした。なお、本研究における 排水処理に係わる評価用原単位は、Table 3 およびTable 4 で示した排水処理水量当たりの原単位を用いているため、 本研究では、排水処理に係わる負荷量ではなく、処理水 量を用いて試算した。電力・薬剤・水使用による $\mathrm{CO}_{2}$ 排 出量については、Table 2 に示した各浄化槽およびディ スポーザの消費電力量、薬剤使用量と Fig. 1に示したデ イスポーザへの供給水量に、Table 3 に示した各 $\mathrm{CO}_{2}$ 排 出量原単位を乗じて求めた。浄化槽から発生する污泥の 輸送工程から排出される $\mathrm{CO}_{2}$ 排出量は、文献值から使用 車両をバキューム車とし、そのバキューム車に係わる燃 費を $4.1 \mathrm{l} /$ 件、走行距離を $16.1 \mathrm{~km} /$ 件 $^{20)}$ を基準としたが、 廃棄物処理工程と同様、污泥の輸送距離を $10 \mathrm{~km}$ から $50 \mathrm{~km}$ まで変化させた場合の $\mathrm{LCCO}_{2}$ についても併せてそ の影響を比較評価した。污泥処理については、下水道統 計 ${ }^{21)}$ を基準に算出した污泥処理費にTable 3 に示した廃 棄物処理（公営）の金額当りの原単位を乗じて年間の $\mathrm{CO}_{2}$ 排出量を求めるとともに ケーキの含水率 $78 \%{ }^{22)}$ とし、廃棄物焼却と同様、污泥焼 却に伴い発生する $\mathrm{N}_{2} \mathrm{O}$ の影響を考慮することとした。

\section{3. 結果と考察}

\section{1 排水処理工程における $\mathrm{LCCO}_{2}$ 評価}

本研究における排水処理工程において、比較評価対象 とした構造例示型浄化槽とディスポーザ対応浄化槽の製
造・施工から運用までの算定段階別 $\mathrm{LCCO}_{2}$ 評価結果は Fig. 2 に示すとおりである。ほぼ全ての工程において、 ディスポーザ対応浄化槽の方がディスポーザの導入にお ける負荷増加により、構造例示型浄化槽における $\mathrm{CO}_{2}$ 排 出量を上回る結果となり、排水処理工程合計を比較する と、約 $7.4 \%$ の $\mathrm{CO}_{2}$ 排出量が増加する結果となった。こ の排水処理工程における $\mathrm{CO}_{2}$ 排出量を各工程別に比較す ると、構造例示型浄化槽およびディスポーザ対応浄化槽 ともに同様な傾向にあり、排水処理プロセスにおいては、 製造・施工段階よりも運用段階の影響が約 $6 \sim 7$ 倍大き いことが明らかとなった。製造・施工段階では、各浄化 槽における浄化槽製造段階および浄化槽施工段階の $\mathrm{CO}_{2}$ 排出量が同様に大きく、これらの $\mathrm{CO}_{2}$ 排出量は、浄化槽 容量にほぼ比例する結果となった。これは浄化槽製造段 階においては、Table 6に示される各部材のうち、浄化 槽駆体および仕切板などの製造に用いられる不飽和樹脂 ポリエステルの製造工程における $\mathrm{CO}_{2}$ 排出量が浄化槽製 造段階の約 $70 \%$ 占めるためであり、その他の内部部材 の変更は、浄化槽製造全体からの $\mathrm{CO}_{2}$ 排出量に大きな影 響を及ぼさないためであると考えられた。すなわち、浄 化槽製造段階から排出される $\mathrm{CO}_{2}$ 量は、主に浄化槽容量 に比例し、その埩化槽の処理方式は $\mathrm{CO}_{2}$ 排出量に大きな 影響を及ぼさないことが明らかとなった。そのため、製 造・施工段階においては、浄化槽本来の余㮃污泥貯留能 力や浄化能力といった処理性能を確保しつつ、浄化槽を よりコンパクト化する技術開発を行うことにより、 $\mathrm{CO}_{2}$ 排出量の削減が可能であることが明らかとなった。また、 本研究では、浄化槽輸送段階における輸送トラックに積 載可能な浄化槽を一定として試算したが、浄化槽のコン パクト化の促進により、輸送トラックへの浄化槽積載台 数を増加させることも $\mathrm{CO}_{2}$ 排出量削減に有効であると考 えられた。 


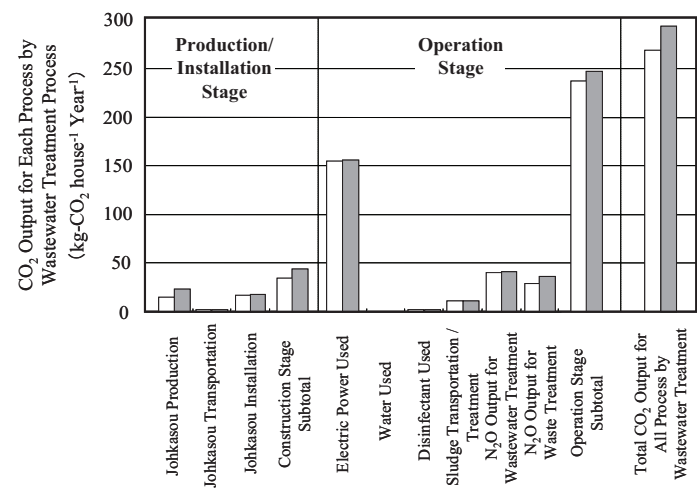

Fig. 2 Comparative analysis of $\mathrm{LCCO}_{2}$ in wastewater treatment process.

$\square$ Johkasou of structural standard

$\square$ Johkasou with disposer

運用段階においては、各浄化槽とも電力使用が運用段 階小計における $\mathrm{CO}_{2}$ 排出量の約 $60 \%$ 以上を占めており、 排水処理工程から発生する $\mathrm{CO}_{2}$ の排出量削減には、ブロ ワの省電力化が最も有効な手段であることが明らかとな った。このブロワの省電力化のためには、ブロワ本体の 効率化による省電力化のみならず、浄化槽本体において も排水の生物処理に必要な酸素溶解効率の上昇やばっ気 槽内の旋回流速の上昇などの対策も有効であると考えら れた。一方、運用段階における排水処理工程や廃衰物処 理工程に伴う $\mathrm{N}_{2} \mathrm{O}$ 発生量が運用段階小計における $\mathrm{CO}_{2}$ 排 出量の約 $30 \%$ 以上を占めている結果となり、排水処理工 程から発生する $\mathrm{N}_{2} \mathrm{O}$ 発生抑制対策も重要課題であること が明らかとなった。排水処理工程に伴う $\mathrm{N}_{2} \mathrm{O}$ 発生抑制対 策は、今後も重要な技術開発テーマであるが、ブロワ供 給風量の増加など、他工程からの $\mathrm{CO}_{2}$ 排出量増加を伴わ ない手法で対策を実施することが重要である。また、污 泥焼却に伴い発生する $\mathrm{N}_{2} \mathrm{O}$ は、高温焼却炉の適正導入 ${ }^{23)}$ などにより削減することが可能であると考えられている。

\section{2 標準処理ケースとディスポーザ対応浄化槽 導入ケースにおける各工程別 $\mathrm{LCCO}_{2}$ 評価}

本研究で比較評価対象としたCase 1 (標準処理ケース) と Case 2 (ディスポーザ対応浄化槽導入ケース) における 各工程別の $\mathrm{LCCO}_{2}$ 評価の結果は、それぞれFig. 3、Fig. 4 に示すとおりである。Case 1では、全工程から排出さ れる $\mathrm{CO}_{2}$ 排出量 $\left(510.8 \mathrm{~kg}-\mathrm{CO}_{2} /\right.$ (戸・年)) に対して、 排水処理工程および廃棄物処理工程のそれぞれの工程か らの $\mathrm{CO}_{2}$ 排出量はほぼ同等で、排水処理工程は全工程の

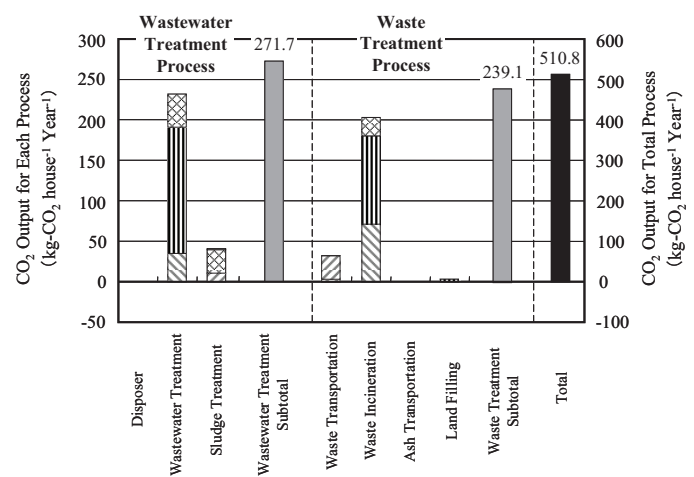

Fig. $3 \mathrm{LCCO}_{2}$ in each process in case 1. $\$$ Production/Installation Stage 血 Electric Power, Water, Disinfectant, Fuel $\square$ Transportation Fuel (Diesel) $\square$ Sludge Intermediate Disposal 网 $\mathrm{N}_{2} \mathrm{O} \square$ Subtotal $\square$ Total

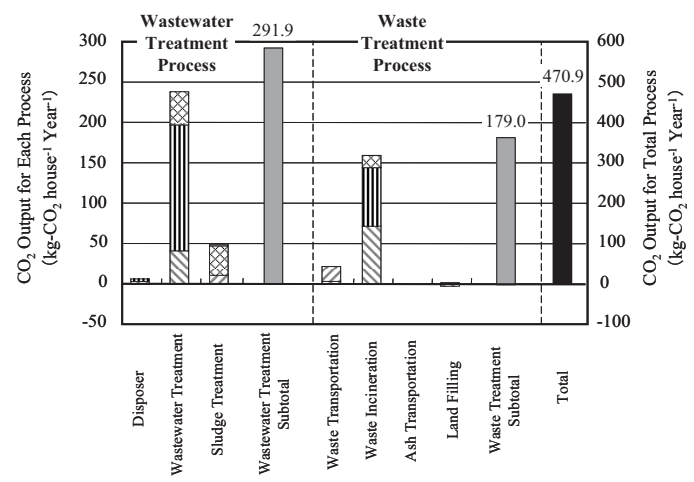

Fig. $4 \mathrm{LCCO}_{2}$ in each process in case 2.

$\mathbb{\$}$ Production/Installation Stage

血 Electric Power, Water, Disinfectant, Fuel

$\square$ Transportation Fuel (Diesel)

$\square$ Sludge Intermediate Disposal

国 $\mathrm{N}_{2} \mathrm{O} \square$ Subtotal $\square$ Total

$53 \%\left(271.7 \mathrm{~kg}-\mathrm{CO}_{2} /(\right.$ 戸 ・ 年 $\left.)\right) 、$ 廃棄物処理工程は全工 程の $47 \%$ （239.1 kg- $\mathrm{CO}_{2} /$ (戸・年)) であった。一方、 Case 2では、全工程から排出される $\mathrm{CO}_{2}$ 排出量 $(470.9 \mathrm{~kg}$ $-\mathrm{CO}_{2} /$ (戸・年)) に対して、排水処理工程からの $\mathrm{CO}_{2}$ 排 出量は増大し、廃衰物処理工程からの $\mathrm{CO}_{2}$ 排出量は減少 するために、排水処理工程は、全工程の62\%（291.9kg $-\mathrm{CO}_{2} /$ (戸・年) )、廃棄物処理工程は全工程の $38 \%$ （179.0 $\mathrm{kg}-\mathrm{CO}_{2} /$ (戸・年)) と変化した。このことから、ディス ポーザ対応浄化槽の導入により、 $\mathrm{CO}_{2}$ 排出割合が廃棄物 処理工程から排水処理工程へ大きく変化することが明ら 
かとなった。また、Case 1 およびCase 2 における排水処 理工程、廃棄物処理工程を各工程別に比較すると、Case 1 と Case 2 ともに同様な傾向にあり、排水処理工程では 排水処理の運用段階における $\mathrm{CO}_{2}$ 排出量が最も大きく、 また、廃棄物処理工程においては、廃棄物焼却の運用段 階における $\mathrm{CO}_{2}$ 排出量が最も大きい結果となった。Case 1とCase 2の $\mathrm{LCCO}_{2}$ 評価を各工程別に比較した結果は Fig. 5 に示すとおりである。Fig. 5 では、Case 1 を基準に、 Case 2 において、 $\mathrm{CO}_{2}$ 排出量が増加する量をプラスに、 また、 $\mathrm{CO}_{2}$ 排出量が減少する量をマイナスとして示して いる。このFig. 5 の結果から、ディスポーザ対応浄化槽 の導入によりごみ輸送、ごみ焼却に代表される廃棄物処 理工程から生ごみ処理に伴い発生していた分の $\mathrm{CO}_{2}$ 排出 量が55. $1 \mathrm{~kg}-\mathrm{CO}_{2} /$ (戸・年) と大きく減少し、一方、生 ごみを排水処理工程で処理する分の $\mathrm{CO}_{2}$ 排出量が $20.2 \mathrm{~kg}$ $-\mathrm{CO}_{2}$ /(戸・年) と生ごみの廃衰物処理に伴い発生して いた分の $\mathrm{CO}_{2}$ 排出量の $37 \%$ しか増加しない結果となった。 また、これらの差分により、生ごみを発生原位置で減量 化させるCase 2 では $\mathrm{CO}_{2}$ 排出量が削減されることが明 らかとなり、Case 1 と比較して、Case 2 において、 $\mathrm{CO}_{2}$ 排出量が $7.8 \%$ 削減 $\left(-39.9 \mathrm{~kg}-\mathrm{CO}_{2} /\right.$ (戸・年)) される 結果となった。

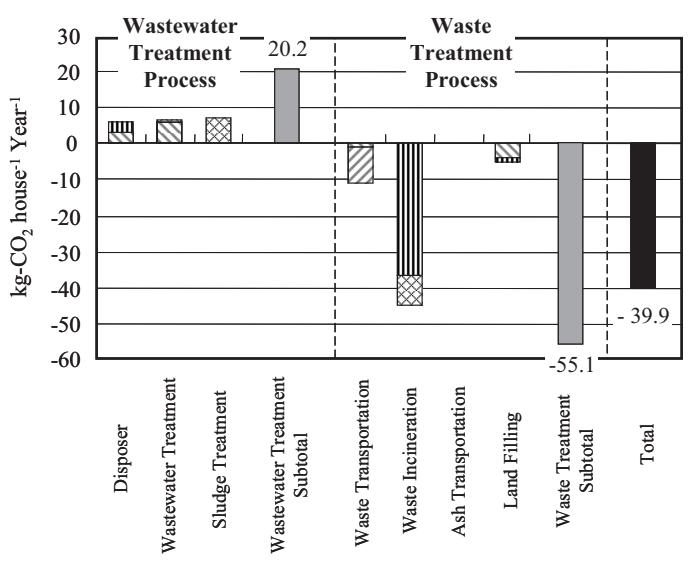

Fig. 5 The balance of $\mathrm{LCCO}_{2}$ between cases 1 and 2 .

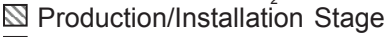
血 Electric Power, Water, Disinfectant, Fuel $\bigotimes$ Transportation Fuel (Diesel) $\square$ Sludge Intermediate Disposal 圂 $\mathrm{N}_{2} \mathrm{O} \square$ Subtota Total

\section{3 生活系ごみ輸送距離および污泥輸送距離が $\mathrm{LCCO}_{2}$ 評価に及ぼす影響}

浄化槽設置地域は住宅密集度が低く住宅間の距離が長 いと考えられるため、生活系ごみの輸送距離を $10 \mathrm{~km}$ か ら50km まで変化させた場合および浄化槽から発生する 污泥の輸送距離を $10 \mathrm{~km}$ から $50 \mathrm{~km}$ まで変化させた場合の Case 1 とCase 2 における $\mathrm{LCCO}_{2}$ 評価結果について比較 検討を行った。污泥輸送距離を基準点である $16.1 \mathrm{~km}$ 一定とし、生活系ごみの輸送距離を $10 \mathrm{~km}$ から50km まで 変化させた場合の $\mathrm{LCCO}_{2}$ の評価比較結果はFig. 6 に示す とおりである。両ケースにおいて、排水処理工程、廃裹 物処理工程全体の $\mathrm{LCCO}_{2}$ は、生活系ごみの輸送距離に 対して一次の相関を示し、Case 1（標準処理ケース）で は、生活系ごみの輸送距離 $1 \mathrm{~km}$ あたり $1.05 \mathrm{~kg}-\mathrm{CO}_{2} /$ (戸・ 年)となり、Case 2 (ディスポーザ対応浄化槽導入ケース) では、生活系ごみの輸送距離 $1 \mathrm{~km}$ あたり $0.70 \mathrm{~kg}-\mathrm{CO}_{2} /$ (戸・年) となった。この結果から、生活系ごみ輸送距 離 $1 \mathrm{~km}$ あたり $0.35 \mathrm{~kg}-\mathrm{CO}_{2}$ /(戸・年) の差が生じること になり、生活系ごみの輸送距離が長い程、 $\mathrm{CO}_{2}$ 排出量の 差が大きくなっていくことが明らかとなった。すなわち、 ディスポーザ対応浄化槽の導入は、住宅密集度が低い地 域ほど、より導入の効果が顕著になることが明らかとな った。一方、生活系ごみの輸送距離を基準点である 30 $\mathrm{km}$ で一定とし、浄化槽から発生する污泥の輸送距離を $10 \mathrm{~km}$ から $50 \mathrm{~km}$ まで変化させた場合の $\mathrm{LCCO}_{2}$ の評価比較 結果はFig. 7 に示すとおりである。両ケースにおいて、 污泥の輸送距離に対して、排水処理工程、廃棄物処理工 程全体の $\mathrm{LCCO}_{2}$ は一次の相関を示す結果となったが、 Case 1（標準処理ケース）では、污泥の輸送距離 $1 \mathrm{~km}$ あたり $0.67 \mathrm{~kg}-\mathrm{CO}_{2} /$ (戸・年) となり、Case 2 （ディス ポーザ対応浄化槽導入ケース）においても、污泥の輸送 距離 $1 \mathrm{~km}$ あたり $0.67 \mathrm{~kg}-\mathrm{CO}_{2} /$ (戸・年) と同じ結果とな った。これらの結果は、浄化槽からの污泥引き抜きおよ び污泥輸送が 1 回/年であるため、排水処理工程、廃棄 物処理工程全体の $\mathrm{LCCO}_{2}$ に対して大きな影響を及ぼさ ないことを示している。これらの結果から、Case 1と 比較して、Case 2では、生活系生ごみを発生原位置で減 量化させ、かつ、原位置で生ごみを処理した結果発生す る污泥を 1 年間貯留できることから、浄化槽から発生す る污泥の輸送距離が排水処理工程、廃衰物処理工程全体 の $\mathrm{LCCO}_{2}$ に及ぼす影響は小さく、一方、生活系ごみの輸 送距離は、排水処理工程、廃棄物処理工程全体の $\mathrm{LCCO}_{2}$ に及ぼす影響は大きいことが明らかとなった。また、そ 


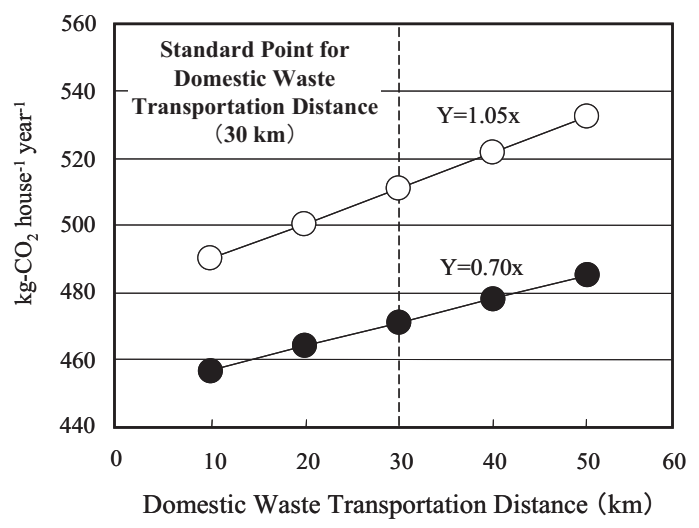

Fig. 6 Effect of Domestic Waste Transportation Distance on $\mathrm{LCCO}_{2}$

$\bigcirc$ Case 1

Case 2

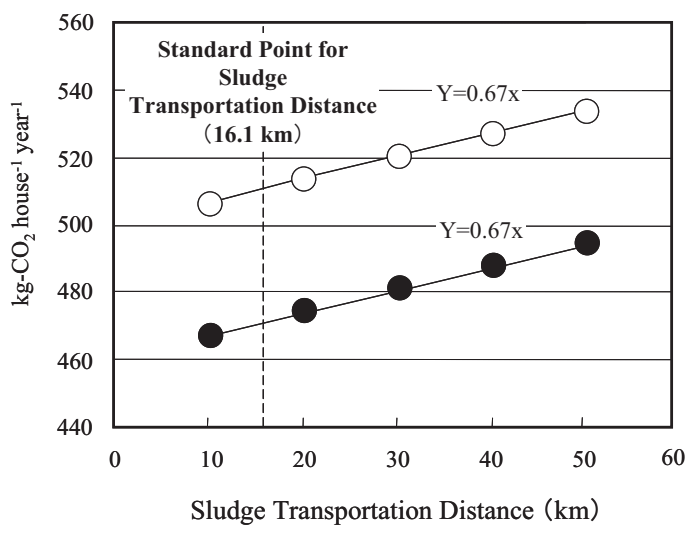

Fig. 7 Effect of Sludge Transportation Distance on $\mathrm{LCCO}_{2}$. Case 1 Case 2

の差は住宅密集度が低い地域ほど、導入の効果が顕著に なることが明らかとなった。

本研究では、構造例示型浄化槽とディスポーザ対応浄 化槽という 2 種の浄化槽を例に、ディスポーザ対応浄化 槽の導入による生ごみの廃棄物処理から排水処理への移 行が地域全体の環境に及ぼす影響を明らかにするために、 $\mathrm{CO}_{2}$ 排出量変化に着目し、 $\mathrm{LCCO}_{2}$ を比較定量評価するこ とにより、廃棄物処理と排水処理という 2 種のプロセス の環境影響評価の考え方について明らかとした。本研究 における試算では、浄化槽を設置する各地域における処 理規模、実使用人員、排水の高度処理、地域特性に応じ た生ごみ量、ディスポーザ対応浄化槽の面整備による生
活系ごみの収集回数削減効果などは検討対象とはしてい ないが、温室効果ガスの削減には、本研究で明らかとし た個別分散型排水処理システムを中心とした排水処理工 程からの温室効果ガスの削減を図るとともに、地域全体 の環境影響を踏まえた対象地域の選定が重要である。

\section{4. まとめ}

浄化槽地域の戸建住宅に、生活排水を構造例示型浄化 槽で処理し、全ての生活系ごみを焼却する標準処理ケー スと生活排水とともに生ごみをディスポーザ対応浄化槽 で処理し、生ごみを除く生活系ごみを燒却するディスポ ーザ対応浄化槽導入ケースを例に、地域全体の廃棄物処 理と排水処理に係わる環境変化を $\mathrm{LCCO}_{2}$ として比較定 量評価した。

本報で得られた知見をまとめると、以下のとおりであ る。

(1)排水処理プロセスにおいては、製造・施工段階よりも 運用段階の影響が約 6 ～ 7 倍大きいことが明らかとな つたため、製造・施工段階より運用段階における $\mathrm{CO}_{2}$ 削減、すなわち、ブロワの少電力化および $\mathrm{N}_{2} \mathrm{O}$ の発生 抑制対策が環境影響上、効果的であることが明らかと なった。

(2)標準処理ケースおよびディスポーザ対応浄化槽導入ケ ースにおける全体の $\mathrm{LCCO}_{2}$ 評価を比較した結果、デ イスポーザ対応浄化槽の導入により生ごみ処理に伴い 発生していた分の $\mathrm{CO}_{2}$ 排出量が大きく減少し、一方、 生ごみを排水処理工程で処理する分の $\mathrm{CO}_{2}$ 排出量は、 生ごみの廃棄物処理に伴い発生していた分の $\mathrm{CO}_{2}$ 排出 量の $37 \%$ しか増加しない結果となった。また、これら の差分により、生活系生ごみを発生原位置で減量化さ せるディスポーザ対応浄化槽導入ケースでは $\mathrm{CO}_{2}$ 排出 量が削減されることがわかり、 $\mathrm{CO}_{2}$ 排出量は $7.8 \%$ 削 減 $\left(-39.9 \mathrm{~kg}-\mathrm{CO}_{2} /(\right.$ 戸・年 $)$ ) される結果となった。

(3)生活系ごみの輸送距離と浄化槽から発生する污泥の輸 送距離を変化させた場合の $\mathrm{LCCO}_{2}$ について、比較評 価を行った結果、浄化槽から発生する污泥の輸送距離 が $\mathrm{LCCO}_{2}$ に及ぼす影響は小さく、一方、生活系ごみ の輸送距離が $\mathrm{LCCO}_{2}$ に及ぼす影響は大きくなる結果 となった。また、その差は住宅密集度が低い地域ほど、 導入の効果が顕著になることが明らかとなった。 


\section{参考文献}

1）国土交通省都市・地域整備局下水道部、国土技術政 策総合研究所下水道研究部：デイスポーザー導入時 の影響判定の考え方 (2005)

2 ）(財)日本建築センター：デイスポーザーによる生ごみ リサイクルシステムの開発 (1999)

3 ) (財)茨城県薬剂師会公衆衛生検査センターホームペー ジ : http://www.ibaraki-kensa.or.jp/disp/

4 ) (財)日本建築センター：浄化槽の性能評価試験方法 (2004)

5 ）豊貞佳奈子、清水康利、大塚雅之：集合住宅用ディ スポーザシステムの環境影響評価その $1 \quad \mathrm{LCCO}_{2}$, LCE 分析用原単位の設定、日本建築学会環境系論文 集、No.574、pp.43-50（2003）

6 ）豊貞佳奈子、清水康利、大塚雅之：集合住宅用ディ スポーザシステムの環境影響評価その 2 デイス ポーザ導入による $\mathrm{CO}_{2}$ 発生量変化、日本建築学会環 境系論文集、No.585、pp.47-53（2004）

7 ）清水康利、山海敏弘、豊貞佳奈子、北口かおり、大 塚雅之：家庭用厨芥処理機器の $\mathrm{LCCO}_{2}$ 評価、日本 建築学会環境系論文集、Vol.73, No.627（2008）

8 ) 西村和之、渡辺孝雄、木曾祥秋：合併処理浄化槽の 整備におけるライフサイクルアセスメント的評価の 応用、浄化槽研究、Vol. 16、No.5 (2004)

9 ) (財)日本建築センター：浄化槽の構造基準 · 同解説 (2006)

10）環境省：平成17年版循環型社会白書（2005）

11）東京都清掃研究所：平成 7 年度東京都清掃研究所研 究報告 (1997)

12）井村秀文：建設のLCA、株式会社オーム社（2001）

13）環境省：一般廃棄物処理実態調査結果、環境省ホー ムページ : http://www.env.go.jp/recycle/waste_tech/ ippan/index.html

14）森口祐一、南斎規介: 産業連関表によるエネルギー。 二酸化炭素排出原単位'95 ( $\beta$ 版)、京都大学大学院 エネルギー科学研究科エネルギー環境学分野ホーム ページ : http://aerosol.energy.kyoto-u.ac.jp/-lca/I-O table/public.html

15）日本下水道事業団：下水道の効率化 -高度化を目的 とした微生物の活用に関する調査（先導的技術開発 プロジェクト）下水道システムにおけるLCAの適 用及び原単位算出手法に関する調査、日本下水道事 業団技術開発部報、pp. 129-137（2001）

16）化学経済研究所 : 基礎素材のエネルギー解析調査報 告書、pp. 135-136 (1993)

17）環境省・経済産業省 : 温室効果ガス排出算定・報告 マニュアル (2007)

18）(社)空気調和 - 衛生工学会 地球環境委員会 : 委員会 成果報告書 建築設備と地球環境に関する研究 (1999)

19）(社)日本建築学会：建物のLCA 指針（案）（2000）

20）(財)日本環境整備教育センター：平成13年度浄化槽の ライフサイクルアセスメントに関する調査報告書 (2002)

21）(社)日本下水道協会：平成14年度版下水道統計要覽、 第59号の 3 (2002)

22）(社)日本下水道協会：下水道施設計画 - 設計指針と解 説後編（1994）

23）平出亮輔、中島英一郎、川嶋幸徳、中島智史、鈴木 善三: 下水道施設から排出される地球温暖化物質 $\left(\mathrm{CH}_{4}, \mathrm{~N}_{2} \mathrm{O}\right)$ 排出インベントリーの算定と排出抑制 技術、下水道協会誌、No.508（2005）

(受付 2008.2.21)

(受理 2008.6.24) 